\title{
MASTER
}

\section{Raman and Infrared Spectra of Pollucite}

\author{
C. M. Hartwig, D. K. Ottesan
}

Sandia Laboratories 


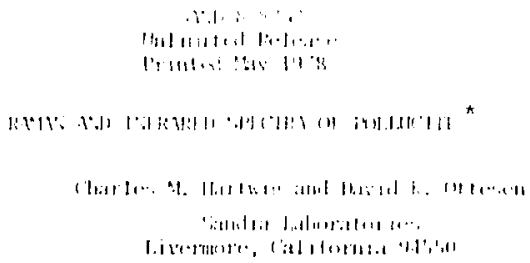

Nin!ll it

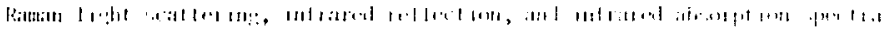

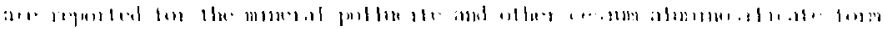

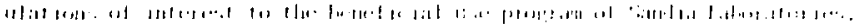

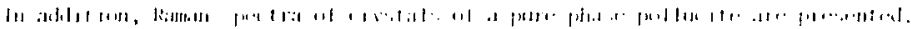

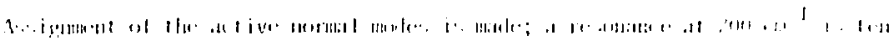

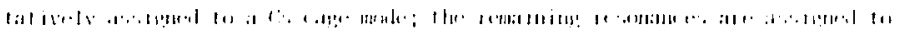

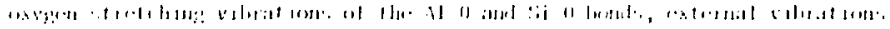

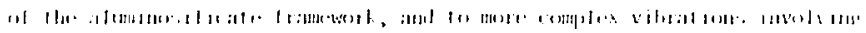

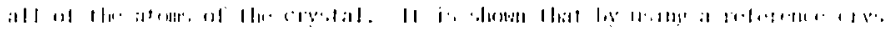

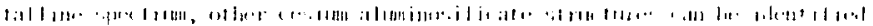

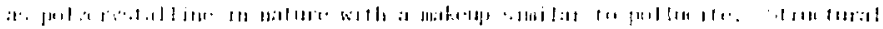

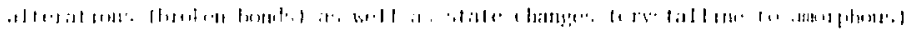

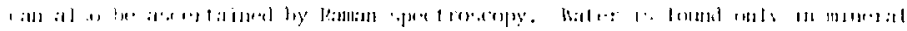

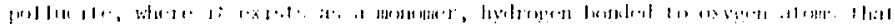

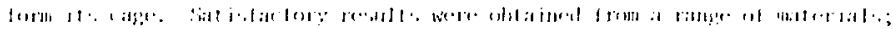

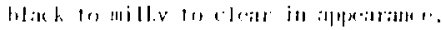

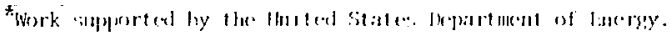




\section{INTROIVLTIO:}

Raman and infrared spectroscopy have been applied to the examination of various cesium aluminosilicates, all similar to the mineral pollucite. The samples cxamined in this study were furnished by J. K. Johnstone/5846. Sandia Laboratory's interest in pollucite is based on the ability of this material to take up proportionately large quantities of Cs. Sandia is planning to exploit this property and use a pollucjte-like material to incorporate (radioactive) ${ }^{1.37} \mathrm{Cs}$, a nuclear reactor byproduct. This material can then l:e used as a gimma-rily source for benelicial use programs. 1

Our chojce of Raman and infrared spectroscopy to examine these samples was motivated by the ability of these techniques to determine atomic structures. These spectroscopies detect vibrational modes that involve the atomic constituents, ind these modes in turn can be related to the structure of the material. In addition to the hasic structure of the material, atomistic defects and molccular jnclusions in the structure can be observed. Examples of these tymes of species are broken bonds and water. Structural information is useful in at least three ways: (1) structural differences resulting from the method of preparation car be found; (2) structural changes as a function of sone interaction, say with gamma radiation, can be assessed; (3) precusors to or the onset of gross mechanical change may be seen. In this last situation, for instance, soft modes that precede the occurrence of solid state phasc changes have been observed with Raman spectroscopy. ${ }^{2}$ U1.timately, information about atomic structure can be related to the mechanical behavior or integrity of the material. 
With these goals in mind we have developed a three point program to study pollucites: (1) to obtain the "reference" Rannan and infrared syectra and to correlate them with the structure of pollucite; (2) to simalate the garouray dose to the material and/or the effects of the transmutation of ${ }^{137} \mathrm{Cs} ;{ }^{3}$ (3) ultimately, to work directly with the radioactive material.

At this point in the study, most of the effort to complete objective (1) has been done. This memo will be devoted principally to the discussion of these results. Sone experiments with radiation simulation will be mentioned briefly. 'Ihe objective of working with hot material will be discussed in the proposed program portion of this paper.

We have included discussions of sample preparation, pollucite crystal symuetry, Raman spectra of crystalline, mineral, and ceramic forms, a crysta1-to-glass comparison, IR spectra, water in pollucite, radiation simulation experiments, conclusions, and a proposed program. 
Three candidate samples of cesiuna aluainusiliciates for ${ }^{15 i}$ Cs incorporation, all similar to pollucite, were examined (Sce lable I). These were prepared by J. K. Johustone, 5846. Fach of these three had a slightly different composition. Samples H-260 and H-275 were prepared from reagent-grade chenicals, while H-273 was manufactured from Csol Montmorillonite clay. A11 were prepared in the same manner: hot pressing a dehydrated powder near 10010 $t$ : These sauples are shown in Figure 1, where 11-275 is milky colored, 11-200 is partially translucent, and $\mathrm{H}-273$ is black. Raman and infrured reflection spectra were successfully taken from all these materials. Rianan light scattering from 11-273 and 11-275 was 1 imited to the near-surface region.

Two other sariple types known to have pollucite formulations were also examined. One was a mineral (See Figure] and Table I for the chemical formulation) and as such was polycrystalline. The others were laboratory-grown, hydrothernal crystals obtained from $S$. $\Lambda$. Gallagher and G. MeCarthy of Pennsylvania State University through J. K. Johnstone. Some of the sma1l crystalline samples on a fixture used for light scattering are show in Figure 2.

In this work we correlate Raman scattering and infrared spectra with the known crystalline structure of pollucite a. look for variations in other cesium aluminosilicate structures based on change in these reference spectra. Follucite has cubic symetry $-\mathrm{O}_{\mathrm{h}}{ }^{10}$ (Ia3d). ${ }^{4}$ Table I 1ists the stoichiometry of the mineral pollucite and of the pure-phase crystals (the hydro-thermal crystals). Other alkali oxides, principally $\mathrm{Na}_{2} \mathrm{O}$, are present in the pollucite mineral. Also, mineral pollucite is known to be a zeolite with four 
water molecules per unit cell. In the case of the pure-phase material, no other alkali oxides are present, and there is no water. In both cases, however, the space group is $\mathrm{h}^{10}$ (Ia $3 \mathrm{~d}$ ). 4,5

Two dimensional projections of four unit cells of pollucite are shown in Figure 3. ${ }^{4}$ An aluminosilicate framework is the basis of the pollucite structure. The silicon and aluminum are fourfold coorlinated with the oxygen atoms, forming tetrahedra that are the basic bullding blocks of the franework. The structure is composed of 4,6 , and 8 momber rings of tetrahedra. The Si and Al ire randomly placed at the tetrahedral sites in the crystal. To establish the fourfold valency of aluminum, an electron is gamerod from an alkali atom. Consequently, in all the aluninosilicate structures with which se will be dealing, the $\mathrm{Cs}_{2} \mathrm{O}$ to $\mathrm{Al}_{2} \mathrm{O}_{3}$ ratio is $1: 1$. In the aluminosilicate lramework, sixteen large cages are formed in each unit cell. These have diameters on the order of $6.8 \stackrel{\circ}{A}$ and contain $\mathrm{Cs}$ or $\mathrm{H}_{2} \mathrm{O}$ molecules. In what follows, we shall be interested in finding the modes that can be characterized with the movements of the bridging cxygen atoms between tetraliedra, modes of the tetrahculral framesork, and modes that predominantly involve $\mathrm{Cs}$.

It should be noted that two other crystalline formulations of cesium aluminosilicate have been found. These are $\mathrm{Cs}_{2} \mathrm{O} \cdot \mathrm{H}_{2} \mathrm{O} \cdot 2 \mathrm{SiO}_{2}{ }^{6}$ and $\mathrm{Cs}_{2} \mathrm{O} \cdot \mathrm{H}_{2} \mathrm{O}$. $\operatorname{IOSiO}_{2},{ }^{7}$ and neither is cubic. In all of our spectral results to date we have seen no evidence of a material that has other than cubic symetry.

RAMAN SPECTRA OF CRYSTALJINE POLLUCITE

The first step in our program has been to obtain and understand the spectra of the pure-phase pollucite crystals as a stepping-stone for interpreting 
structural alterations that misht ocorr in other cosium alunjnosilicates. We are most fortunate to have crystals of the pure-phase material and a siblple of the mineral to exanine. As mentioned, hoth materials have a space group symmetry of $\mathrm{o}_{\mathrm{h}}{ }^{10}$. The crystals are very complex and have a large number of atoms in the primitive cell, resulting in some 250 normal modes for the purephase crystal. Not all, however, are either Raman or infrared active, as shown in Table II. Also shown in Table 11 are the polarizability tensors and infrared activities of appropriate modes. Because the irreducible symmetry inversion operator is one of the space group operations of $c_{b}{ }^{10}$, the active nodes are cither laman active or infrared, hut not both.

Theoretically, the $\mathrm{A}, \mathrm{B}$, and $\mathrm{F}$ modes [the singly, doubly and triply degenerate modes) that are Raman active can be djstinguis'ed. liowever, this resolution neces!sitates alignnent of the crystallographic axes with the scittering axes of the equipment. Clearly, this procedure cannot be clone in the case of the polycrystalline samples. Unfortunately, the pure-phase crystals were very sllall polyhedra clumed together with dimensions 2 150,m; consequently we have not yet been able to aljgi the crystallographic axes with the scattering axes of the crystals. Nevertheless, the $A$ modes can be separated from the $E$ and $F$ modes; the A modes have a diagonal polarizability tensor, and therefore, under any coordinate axis rotation, the scattering from them will remin polarized. This property is not the case for the $E$ and the F modes; they wil! present both polarized and depolarized spectra.

Tabie II also 1 ists the atons that participate in the various symotry modes. The normal modes are built up from the symetry modes of the same irralucible character. The interesting point is that for the Raman-active modes, only 
those modes of $F$ or $F$ character will contain a mode that involves the motion of Cs. Further, the number of these is 1 imited to 2 .

A comparison of the polarized and depolarized spectra from pure-phase politucite is shown in Figure 4. A tist of the identifiable resonances seen in pure-phase pollucite is in Table III, along with the assignment of the appropriate irreducible symetries. Due to the crystal complexity no attempt has been male to determine completely the atomic contribution to all of the nomal modes of pollueite. A qualitative statement about the atonic character of these modes can be made, however. The band at $1100 \mathrm{~cm}^{-1}$ is the oxygen stretch of the Sin bond. This band has been identifiod with the oxygen stretch of the $\mathrm{A}-\mathrm{O}$ bond.

Both of these hands are composites of several normal resonances involving oxygen movement. A series of sharp and symetrical resonances dominate the spectrit! at lower frequencies from about 498 to $70 \mathrm{~cm}^{-1}$. All of these except onc, we believe, are vibrations of the alminosilicate tetrahedrit in the crystallinc. franework. The one exception is the band at $200 \mathrm{~cm}^{-1}$. We will rescrve discussion of this mode to the comparison of the mincral with the pure-phase material. Finally, a series of resonances has been detected between 500 and $100 n$ $\mathrm{cm}^{-1}$, and these are complex vibrations involving all of the atoms of the unit cell.

A comparison of the Raman spectrum from the mineral and that from the purephase material is shaw in Figure 5. Resonances seen in the mineral are listed in Table III. The spectra fron the two materials are remarkably similar. The oxygen stretching bands are in agreement, as are modes associated with the external vibration of the framework. Furthermore, when the weak bands in the 
material coulal be detected they too inged. The mode at $200 \mathrm{om}^{-1}$, homeres. is very weak in the muneral in comparison to the pure-phase material. In the crystal spectnon this mole was assigned to the itrelixible symetry of $i$, or $f$. Now in the mineral there are 12 atoms of Cs per unit ce 11 instrad of the 16 that exist in the pure-phase crysta1. In the positions of the missing Cs atom are water molecules. The weakening of the mode is probably due to the loss of translat ional regularity of the chatoms, implying that this mode involves the participation of Cs. Supportive of this assigument is the observation that in the Argon matrix fornation of $6 \mathrm{sO}_{q}$, low freplency moles near $200 \mathrm{~cm}^{-1}$ have also been observed. Thus, $200 \mathrm{~cm}^{-1}$ resonance most I ikely involves Cs atoul fillt $i_{L}-i_{j}$ iltion.

\section{RMMN SIPCIRA OF: CIRNIIC CI:STIM AJURINOSIIICATES}

Two of the SLA-prepared materials appeared to be ceramic or polycrystalline materials. This conclusion is rather straightfonward when the Ruman spectra of the ceranics are conpared with that from the crystals (See figure 0 ), and also when the resonant fretuencies are compared (See lials [11). In Figure 6, spectra from the crystal pollucite, the mincral pollucite, and the pollucite samples 11-275 and H-273 are displayed. There is good agreement among most of the resonames in frequency position, relative intensities, and Jine shapes, from this general agrement it can be inferred that their basic structure is very similar. In addition, from the fact that most of the lines are symactric and sharp, it can be argucd that the scattering is occurring from a system of highly regular order, i.e., crystals. Finaly, the widths of these symmetric lines indicates that the crystalline sizes are at least on the order of the wavelength of $1 \mathrm{ight}, 5000 \mathrm{~A}$. 
There are sme differences amongst these spectra, as can be seen in the frequency regime near $1000 \mathrm{~cm}^{-1}$. Here one material (11-273) exhibits a different behavior: an extra band appears at $973 \mathrm{~cm}^{-1}$, and there is weakening of the bands at 1000 and $1100 \mathrm{~cm}^{-1}$. A possible explanation for this behavior is the disruption of the Si-O-Si or A1-0-Si bonds joining tetrahedra. The bands at 1050 and $1100 \mathrm{~cm}^{-1}$ previously were associated with this bridging. Other studies have identified a band near $973 \mathrm{~cm}^{-1}$ in silicate materials as being due to the oxygen stretch of a dangling or non-bridging Si-O bond. 10, 11 Lattice disruption - resulting in dangling oxygen bonds - might be expected at that sample, because it wis mate from Montmorillionite clay and CsOl. The clay contained a large percentage of impurities which, when incorporated into the material, could break oxygen bonts connecting tetrahedra. (See Table II.) Another interesting observation, based on the comparison of Raman spectra, is that in going to the silica-rich formulation of cesium aluminosilicate (H-275) the basic structure does tot seem to have been altered mich from that of pollucite. Apparently the basic aluminosilica tetra hedral framework is retained, with proportionally more silicon atoms than aluninufi atoms in the H-275 formulation. This premise is also in agreement with the obsorvation that the band at $1000 \mathrm{~cm}^{-1}$ (the Al-0 stretch) in comparison to the band at $1100 \mathrm{~cm}^{-1}$ (the $\mathrm{Si}-\mathrm{O}$ stretch) is weakened in the case of $\mathrm{H}-275$ as compared to the pure-phase pollucite. Note also that the band at $390 \mathrm{~cm}^{-1}$ is strengthened relative to the hand at $300 \mathrm{~cm}^{-1}$ in increasing the Si content in $11-275$ from the crystalline material. This result suggests that the mode at $390 \mathrm{~cm}^{-1}$ involves $\mathrm{Si}_{\text {, }}$ while that at $300 \mathrm{~cm}^{-1}$ involves Al. 


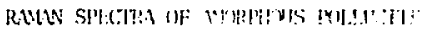

In Figure 7, a comparison of the Ramen spectra from simple II- Itil and irtitiline pollucite is shown. It contrast to the "inilarities discussed hefore, now significant differences between the spectra can he noted. New Rarlintat ive modes have appeared, bands have broadened, and the symetrical shape of tice bints has been lost. All these features highlight the conclusion that there is a difference in the state of the material, and it cin be shown that this difference arises be cause the 11-260 sample is amorphous.

[ncluded in aigure 7 is a Raman spect mun of a vitrcous siltca, Suprasil 2. There are a number of notable similarities between it and that of $11-260$; for instance, the broad structureless scittering helow $400 \mathrm{~cm}^{-1}$, and the al ignuent of a number of peaks. This comparison underscores our conclusion that $\mid 1-2$ an is amorphous. Additionally, there have been reports of Raman spectril of other temary systems, similar to the one that we are dealing with, which were know to be amorphous. Figure 8 is a reproduction of spectra obtained from sodiun horosilicate glasses, about which the author concluted that he wis deal ing with a glassy system, predominately $\mathrm{SiO}_{2}$ in nature. ${ }^{12}$ There is a remarkable sinalarity between the spectrum labelled 3 and that obtaind for II-260, which further: strengthens our conclusion that $\mathrm{H}-260$ is a glassy material.

Some additional conclusions about the character of various resonances an be made in intercomparing the three spectra in Figure 7 . Vitreous silica, in one important feature, is very ruch like the aluminosilicate natirials: it i made up of interconnected tetrahedra. In the case of silica they are all $;$; tetrahedra, and - in the vitreous state - randonly connected. Now note thit 
in both cesium aluminosilicates there is a band near $300 \mathrm{~cm}^{-1}$, which does not occur in vitreous silica inklicating that this mode involves Al. A band near $400 \mathrm{~cm}^{-1}$ exists in all these spectra. This band previously has been identified as involving $\mathrm{Si}^{13}$; it is appropriate in the case of pollucite to do so also. Furthermore, in silica the band at $800 \mathrm{~cm}^{-1}$ is known to be due to oxygen in plane-stretch of the Si-O-Si bond. ${ }^{13}$ Again, we will make this assignment in the cesium alominosilicates. he are left with two bands that are coincident in these materials that have not been satisfactorily identified in vitrous silica: those at 480 and $600 \mathrm{~cm}^{-1}$. We tentatively suggest that the mode at $400 \mathrm{~cm}^{-1}$ is an external vibration of the framework with the tetrahedra noving as unjts, and the $600 \mathrm{~cm}^{-1}$ node quite possibly depends unon sone local coordination of atoms in neighboring tetrahedra.

\section{IR SPECTRA OF POLLICITE AND CERAMIC CISIUN ALIMINOSILICATES}

By far the sirmplest method of obtaining IR spectral data for thick, insulating materials (such as the present pollucite samples) is to examine the material by specular reflection of a near-nomal indicent beam. Unfortunately, large thanges in the refractive index across vibrational bands distort the band shapes and intensities relative to trasmission IR measurements and Raman spectra. To avoid this difficul iy we proceeded by the well-known technique of suspending a few milligrams of jaterial in an IR-transparent $\mathrm{KBr}$ pressed disc.

These absorption spectra from the region 400 to $1500 \mathrm{~cm}^{-1}$ are presented in Figure 9. Reflection spectra from 109 to $1500 \mathrm{~cm}^{-1}$ are shown in Figure 10 . From a comparison of observed Raman and IR frequencies in Table III, the noncorrelation of modes for the two techniques, as predicted by the selection 
rules for the crystalline raterials, is confirned. In agrcenent with the Raman spectra, the IR bands for the pure-phase raterial appear slightly broader than for the crystalline materials, consistent with the presence of an anorphous phase. This broadening is most noticeable in the bands between 700 and $800 \mathrm{un}^{-1}$; however, the effect is not nearly as apparent as in th: Raman spectra.

The intense band around 1030 to $1050 \mathrm{~cm}^{-1}$ for all sarples; is conposed of a muber of modes; its center is shifted down considerably from the analogous peak of $1090 \mathrm{~cm}^{-1}$ observed in vitreous silica, but correlates well with IR spectra for other aluminuosilicates. (Kaolin clay, for example, has a hroad, multistructured band in this region with a ruiximum intensity at $1035 \mathrm{~cm}^{-1} .14$ ) The peaks near 760 to $780 \mathrm{~cm}^{-1}$ correspond to a peak in vitreous silica at $790 \mathrm{~cm}^{-1}$, while peaks from 750 to $625 \mathrm{~cm}^{-1}$ correspond to observed bands in alunina ( $\mathrm{N}_{2} \mathrm{O}_{5}$ ).

The very intense band observed in all the reflection spectra from 445 to 455 $\mathrm{Cm}^{-1}$ is observed in both $\mathrm{Al}_{2} \mathrm{O}_{3}$ and $\mathrm{SiO}_{2}$. The remaining observed IR band is a sharp peak seen in the reflection spectra at $156 \mathrm{~cm}^{-1}$ in all cases. While there are bands observed at $i 50$ and $170 \mathrm{~cm}^{-1}$ for $\mathrm{SiO}_{2}$ and $\mathrm{Al}_{2} \mathrm{O}_{3}$, respectively, these are very weak features compared to the present data. Although it is conceivable that the feature at $156 \mathrm{~cm}^{-1}$ could be related to $\mathrm{Cs}$ atom motion, a more positive assignment must awail definitive experiments with similar aluninosilicate systems not containing Cs.

WATER IN POLUUCITE

A search was conducted for water in all of the pollucite materials. In the glass, ceramic, and pure-phase crystalline pollucite materials, no detectable quantity of $\mathrm{CH}$ was found in either Raman or IR spectra. 


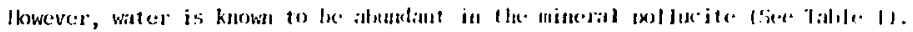

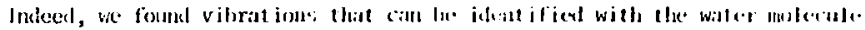

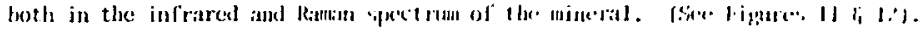

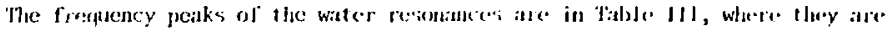

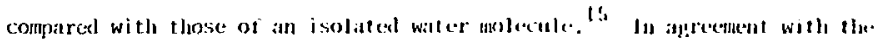
isolated water molecule, the three patks icent in polluteile have the cortert

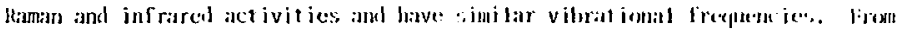

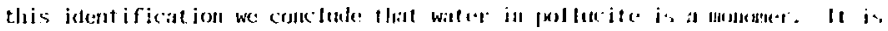

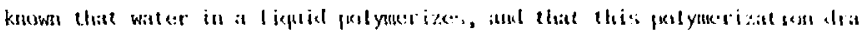

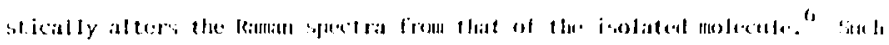

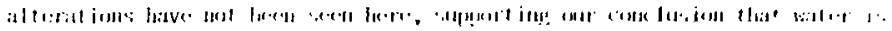

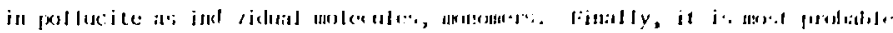

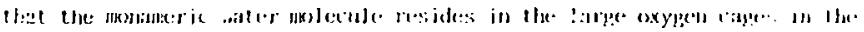

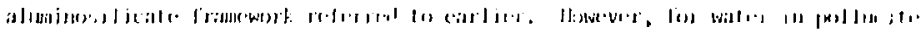

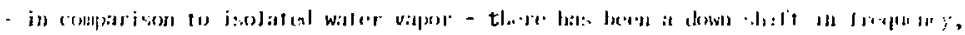

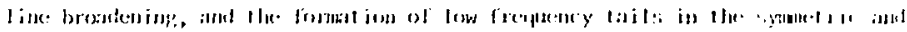

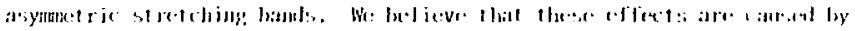

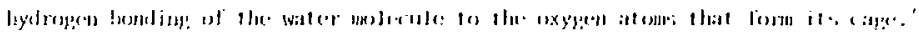

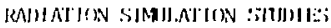

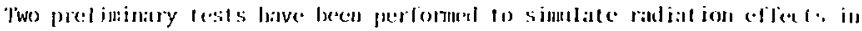
polfucite. In the list, the thres sis

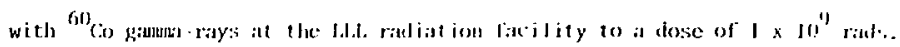
In the post-test examination no alteration of the Ranan spectril wis obsesved. Another raliation test was triel will inconclusive restalts. Simples II 273

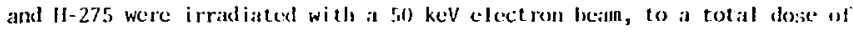




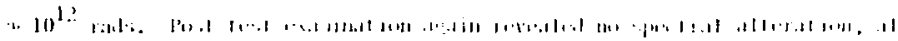

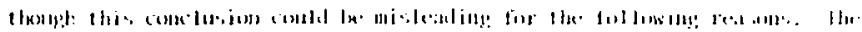

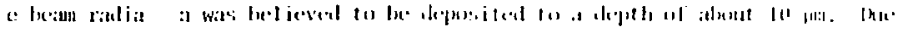

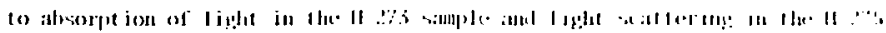

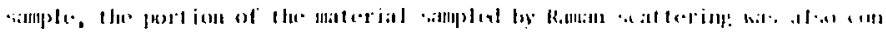

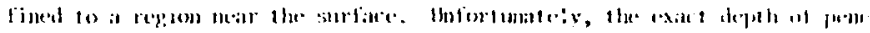

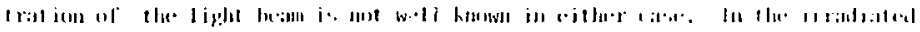

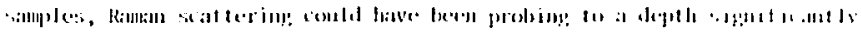

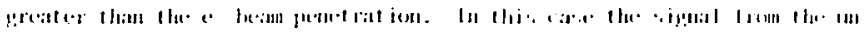

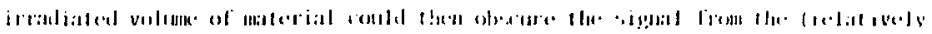

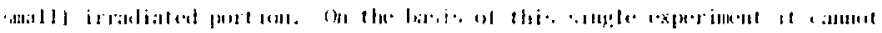
la. $\cdot$. level of ratliat inu.

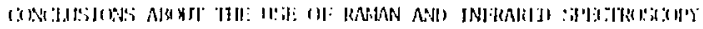

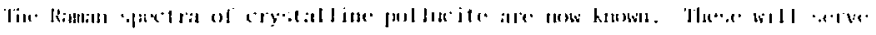

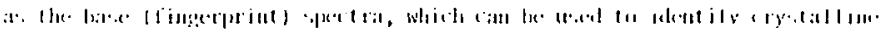

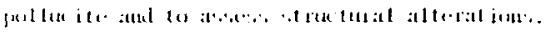

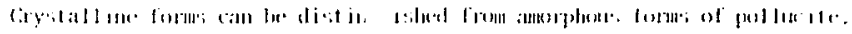

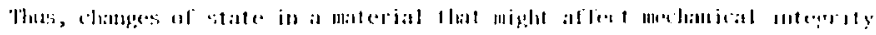

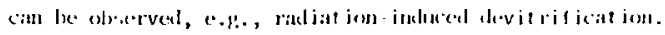

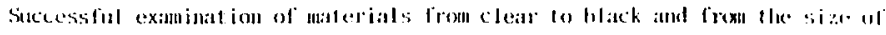

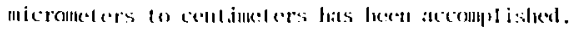


A program is proposed to accomplish the three objectives outlined above: the characterization of pollucite, radjatjon siaulation, and working, with radioactive material.

A. Characterization of Pollucite

Definite progress has been made in identifying and unrave't ing the laman and IR spectra of crystalline pollucite. Nuditionil effort is needed, however, to verify the modes associated with (is. Jwo approaches will be taken. 'the first will involve aligning the crystalline pollucite with the optjal axis of the scattering experi ment allowing the separation of the $\mathrm{l}_{1 \mathrm{~g}}$ and $\mathrm{F}_{2 g}$ moles. The secound is to compare the Raman spestri of pollucite to analcille, which has the identical crystal structure to pollucite, but does not contin Cs." Jhe appropriate Raman spectra must be olstained in the liboratory.

Further chatracterization will be necessiry of the fom of pollucite selected to be used in the beneficial-use program. Ramin and infrareri spectroscopies, as demonstrated, conld be usel to obtann important structural information about these materials. Thus, Raman and Ik measurements should be included in the stalies to develop pollucitelike materials for the beneficia! -use program.

13. Radiation Simulation

Pollucite could receive doses approaching $10^{13}$ rads during the proposed 90 year source lifetime. Possible ways of sinulating this dose include ${ }^{60} \mathrm{Co}$ and e-beam irradiation. Presently very hot ${ }^{60}$ ro sources 


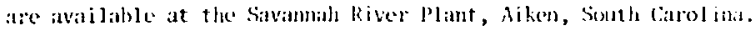
Use might be blale of this faciljty. furthemore, las discussicd atirve), Lat ial it tempte with e-bean raliation bave alrealy been tried. It is proposed that these experiments he expauded, in conjuntion with deterninations of the optical skin deptl of the appropriate materials.

Another method to achieve radiation deposition alone (hithout transmutition) would be to make use of the Cs-pollucite sources plamed for fabricat ion at oak Ridge. llere the base stuterial, not inorjorating the radionctive cs, could be placed arounl the hot simple. is These samples could be periodically renowed and exanimed in the latsoritory.

Finally, it is known that a major effect on the crystal sitructure could come about through the transmutation of $6^{+1} 10 \mathrm{Bat}^{+2}$. Whis valence change could disrupt the crystal structure. Nout ron irraliation experiments have been used before to simulate tramsmatition, for example, the conversion of boron to helitun in borosilicate plasses. Such neutron-generated transmutation elfects miglut he used to simulate valency changes in pollucite. 20

C. Ixannination of Radioactive Material

Romote Rantan spectroscopy could be used to examine hot materials. This procedure could be accomplished fairly easily, because only three types of apparatus need be placed in the ratiation envjronment. These would include two lenses - one for focusing the laser into the sample and the other for collecting the scattered light - mirrors to direct the 1 ight 
beans, and positioning stages. All of the sophisticated cyuipnem, including the laser, spectroneters, and electronics, would be outside the radiation enviroment. These sampling techniques are alrealy bein! developed for use with tritiun in the Tritiun kesearch Laboratory at SLL. Such a systen might be desigmed for hot cell use at SIA.

\section{ACKNOW.IBGGMINYS}

Dr. L. A. Rahn has given us much useful advice in the interpretation and settink up of the Raman experinents. S. Viscy has been of valuble assistance in sett in! us) and designing the technical aspects of the exporiment, and 1. Otta collecterl the majority of the infrared clata. 


\section{References:}

1. This progran is being conducted at Sandia laboratories, Albupuerpute. Responsibility for the material development resjeles with J. k. Johnstone.

2. I. F. Scott, "Soft Mole Spectroscopys: lixperimental Siudies of St nuctura! Phase Transitions," f'ev. of Mod. Pliys. 46 (J), 83 (74).

3. K. W. Molan, "Radiation !isplacement Iamage lstimates for a Radionucl ide Wasto Stabilization Metarial," SAVI)76-826) (1/77).

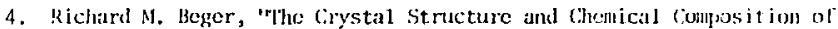
follucite," Zest fur Kristal., 129 280 (b?); R. I:. Newnharl, "(ryetal Structure and ontical Properties of l'ollucite." Nus. Miner. 52, 1515 (67).

5. S. A. Gallagher and (i. J. Mefarthy, "Jeparaion and X-Hay Charatcrization of CsMSsion," Mhte. Ros. 1k11], 12, 1183 (77).

6. R. M. Barrer ant N. M. Callum, "Hychothermila] Chemistry of Silicittes," I. (7icm. Soc., 4(12) (53).

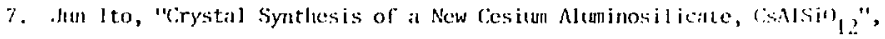
Al1. $19 \mathrm{in}, 01,170(76)$.

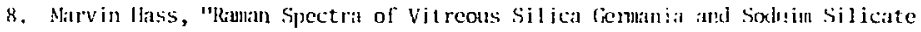
(i)asses," .1. Phys. (heml. Sol. 31, 415 (6!1).

9. Rohert (i. Milkey, "Infrared Spectra of Some Tectrosilicates," Nner. Miner. 45, $990(60)$

10. J. I1. Mackenzic, el. Molern Asjects of the Vitreous sitate lbut terworths, landau, 1960), p. 136; R. J. Bell and P. Rean, "like l,ocalized Vibrat ions of Non-Bridging Oxygen Atoms in Vitrcous Silica," local ized fxcitat ions in Solids, Jroc. of fijst Int. lionf. at U.C. I rvine [P] entun Press, N.Y., 1968).

11. Charles M. lartwig and Larry A. Rahis, "Bound Ilydroxyl in Vitreous Silica," J. of Chem. Phys. 67 (9), 4260 (77). 
12. T. A. Sidorov, V. A. Tylukin, and W. V. Prudrikora, "Raman, EPR, Infrared, and Electronic Absorption Spectra of Sodilm Borosilicate Glasses," Zh. Prik. Spectr. $9(6), 992(68)$.

13. P. Dean, "The Vibrational Properties of Disordered Systems: Mumerical Studies," Rev. of Mod. Phys. 44 (2), 127 (72).

14. R. A. Nyquist and R. O. Cage1. Infrared Spectra of Inorganic compounds (Academic Press, New York, 1971).

15. Gerhard Herzberg, Infrared and Raman Spectra (D. Van Nostrand Company, Inc., Princeton, N.J., 1968).

16. W. F. Murphy and H. J. Bernstein, "Raman Spectra and an Assignnent of the Vibrational Stretching Region of Water," J. of Phys. Chen. 76, 1147 (72).

17. Charles M. Hartwig and Larry A. Rahn, "Anomalous Hydroxyl Modes in Vitreous Silica," Bull. of the APS 22 (3), San Diugo, CA, March 7.

18. The suggestion was made by Larry A. Rahn.

19. V. O. Altemose, "Outgassing of Glass caused by Thermal Neutron and Gäma Radiation," J. of Am. Ceramic Soc. 49 , 446 (66).

20. Such a technique has been suggested by John Vitko, Jr. 
lable I

Cesinn Alumina-Silicate Samples

A. Hot Pressed Powders

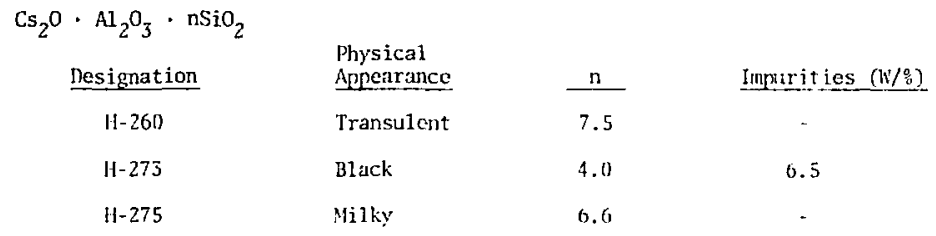

B. Crystals

Minera1

$6 \mathrm{Cs}_{2} \mathrm{O} \cdot 2 \mathrm{Na}_{2} \mathrm{O} \cdot 8 \mathrm{AL}_{2} \mathrm{O}_{3} \cdot 32 \quad \mathrm{SiO}_{2} \cdot 4 \mathrm{H}_{2} \mathrm{O}$

Pure-Phase

$\mathrm{Cs}_{2} \mathrm{O} \cdot \mathrm{Al}_{2} \mathrm{O}_{3} \cdot 4 \mathrm{SiO}_{2}$ 
Table III

Mode Frequencies of Pollucite

$\underline{\text { Raman }}$

\begin{tabular}{|c|c|c|c|c|c|c|c|c|c|c|c|c|c|c|c|c|c|c|}
\hline Crystal & A & & $E+F$ & $\mathrm{E}+\mathrm{F}$ & $?$ & A & $E+F$ & A & 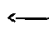 &.- & 工 & 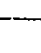 & $-E+F$ & $\cdots$ & & & & \\
\hline Polarized & 69 & & 140 & 200 & & 297 & 393 & 477 & & & & & & & & & 1044 & 1114 \\
\hline Depolarized & 69 & & 141 & 201 & & 297 & 392 & 477 & 559 & 610 & 652 & 711 & & 807 & 861 & 920 & 1016 & 1108 \\
\hline Mineral & 71 & 115 & & 197 & 268 & 297 & 392 & 478 & 520 & & 667 & & & & & & $104 j$ & 1120 \\
\hline $11-273$ & 72 & & 129 & & 277 & 296 & 387 & 472 & & & 670 & & & & & 973 & 2076 & \\
\hline $\mathrm{H}-275$ & 82 & 106 & 133 & 205 & 271 & 300 & 388 & 476 & & 597 & 667 & 709 & 771 & 809 & 851 & & 1044 & 1114 \\
\hline $\mathrm{H}-260$ & & 107 & & & & & 383 & 485 & & & & & & 788 & & & 1002 & 1122 \\
\hline
\end{tabular}

Infrared

$\begin{array}{cc}H-260 & \text { F } \\ H-273 & 155^{*} \\ H-275 & 155^{*} \\ & 155^{*}\end{array}$

Mineral

S-Shoulder

* - Reflection Spectra

Nater in vineral pollucite

Ramaan 3602

IR $\quad 3650,3545^{\mathrm{S}}, 1627$

$\begin{array}{cccccccccc}F & F & F & F & F & F & F & F & F \\ 384^{*} & 455^{*} & 595 & & 720 & 775 & & 1000^{5} & 1050 & 1180^{5} \\ 384^{*} & 442^{*} & 622 & 690^{5} & 728 & 758 & & 995 & 1040 & 1190^{5} \\ 384^{*} & 446^{*} & 626 & 690^{5} & 727 & 761 & & 980^{5} & 1030 & 1125^{5} \\ & 441 & 625 & 695^{5} & 732 & 763 & & 1032 & 1120^{5}\end{array}$


Table Il

Normal Modes for Srysta1!ine Pollucite $o_{h}{ }^{10}$ (Ia3d)

\begin{tabular}{|c|c|c|c|c|c|c|}
\hline & Raman & IR & No. of & \multicolumn{3}{|c|}{$\begin{array}{l}\text { Synmetric Mode } \\
\text { Composition }\end{array}$} \\
\hline Character & Polarizability & netive & Modes & 0 & $\mathrm{Cs}$ & $\mathrm{Al} \& \mathrm{Si}$ \\
\hline $\mathrm{A}_{1 \mathrm{~g}}$ & $x X+Y Y+z z$ & & 4 & $\checkmark$ & & $\checkmark$ \\
\hline $\mathrm{E}_{\mathrm{g}}$ & $\begin{array}{c}X X+Y Y+Z Z \\
3(X X-Y Y)\end{array}$ & & 10 & $\checkmark$ & $\checkmark$ & $\checkmark$ \\
\hline$F_{2 g}$ & $X Y, Y Z, Z X$ & & $\frac{14}{28}$ & $\checkmark$ & $\checkmark$ & $\checkmark$ \\
\hline$F_{1}$ & & $X, Y, Z$ & 16 & $\checkmark$ & $\checkmark$ & $\checkmark$ \\
\hline
\end{tabular}

Total number of nomal modes $=250$ 
ir.

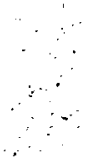




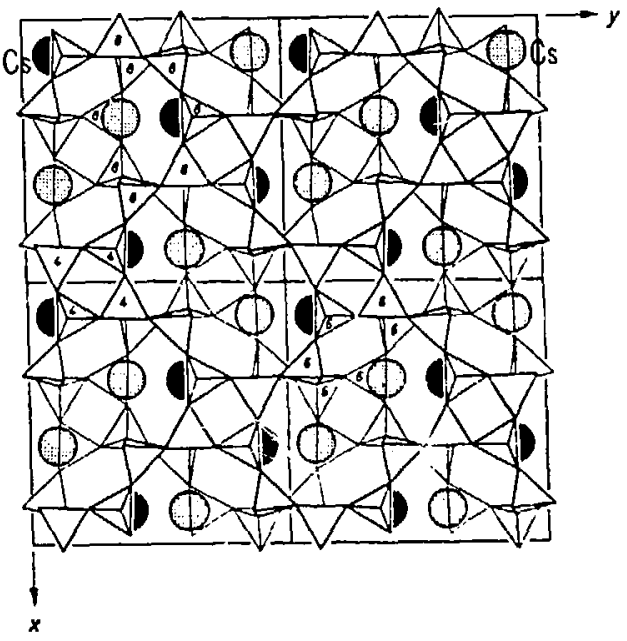

Figure 3, Two dimensional Projection of Four Init Cells of Follucite. ${ }^{4}$ The solid circles are $C s$ atoms $1 / \delta$ of the side of a unit cell above the bottom face and the shaded circles are $3 / 8$. 


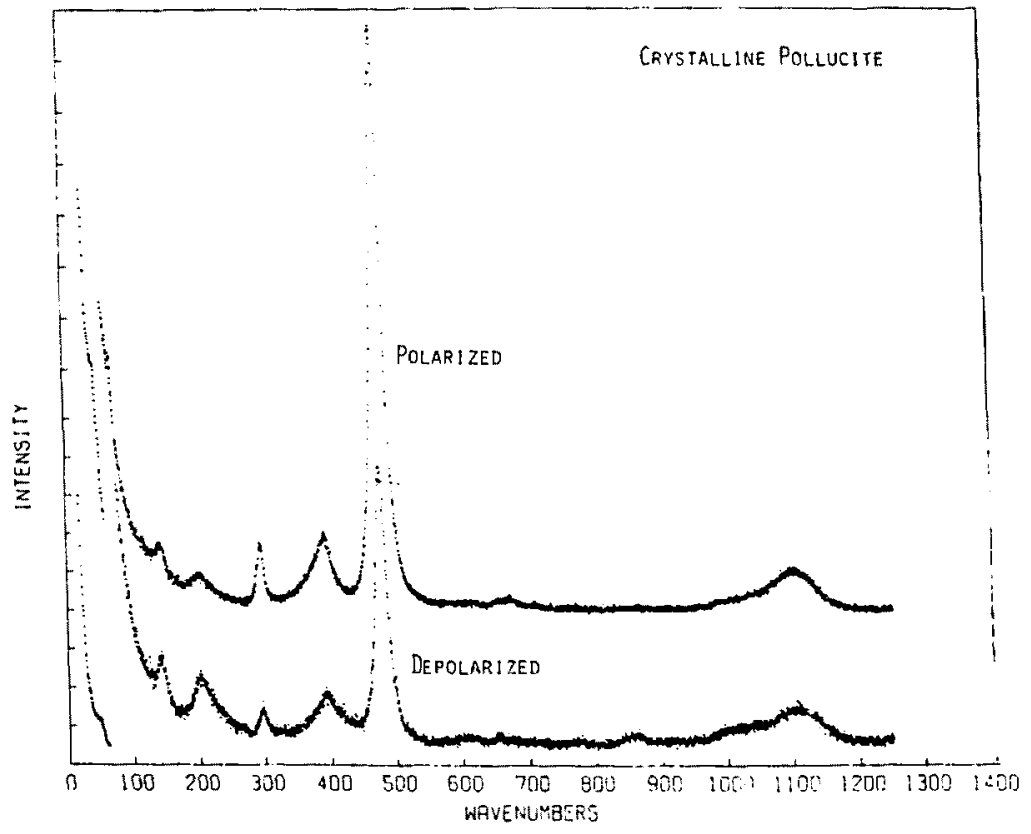

Figure 4. Polarized and Depolarized Raman Spectra of Pure-phase, Crystalliuc Pollucite. 


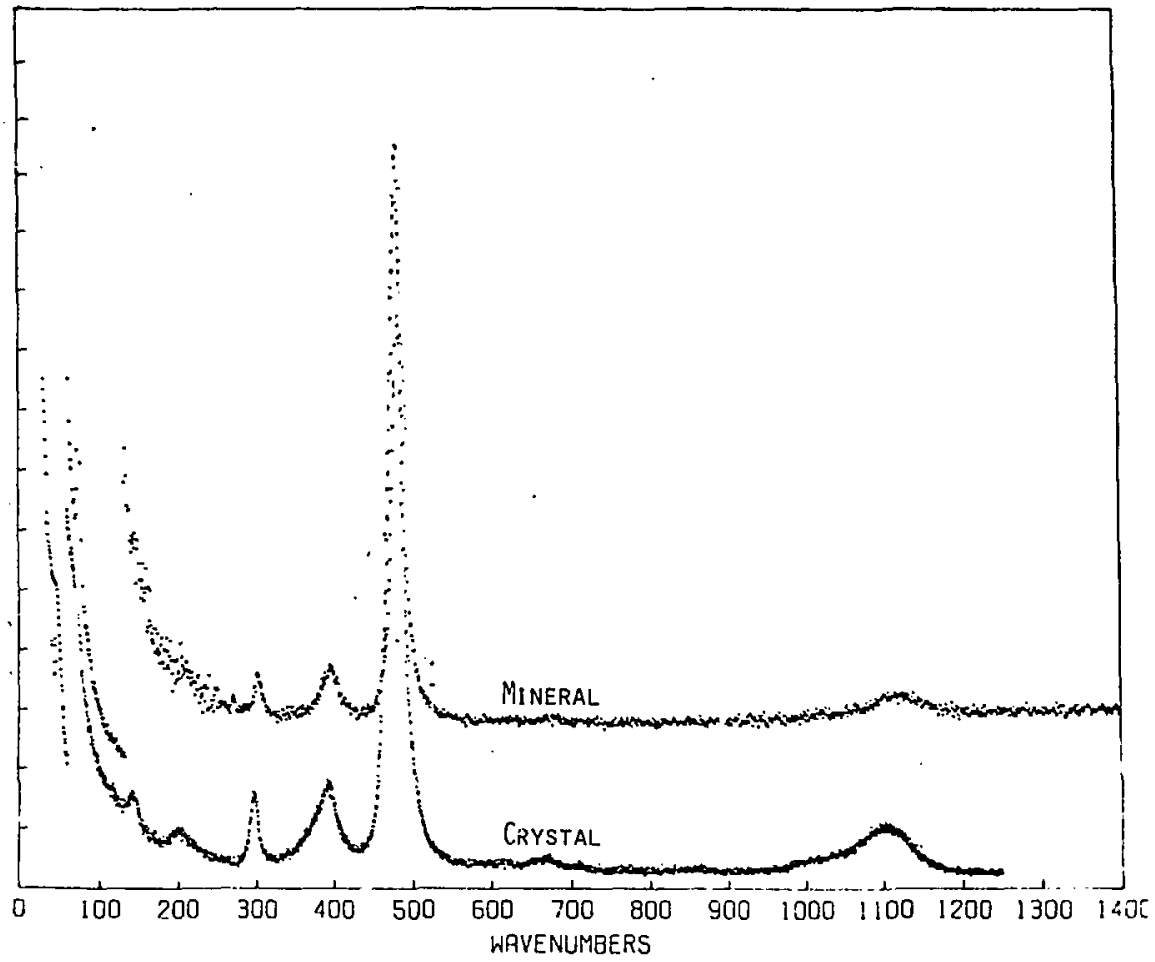

Figure 5. Raman Spectra of Pute-Phase, Crystalline Pollucite and Mineral Pollucite. 


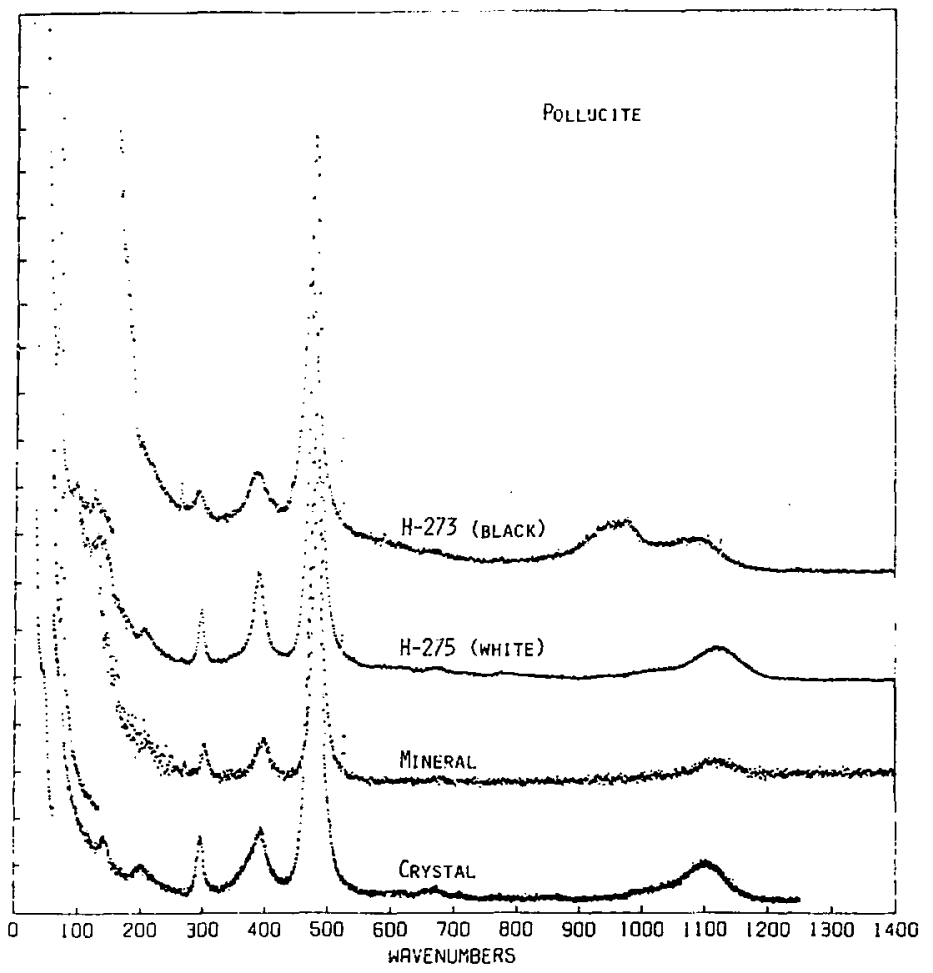

Figure 6. Raman Spectra of Crystalline Forms of Cesium Aluminosilicate Materials. All of the samples examined were crystalline on polycrystalline materials. 


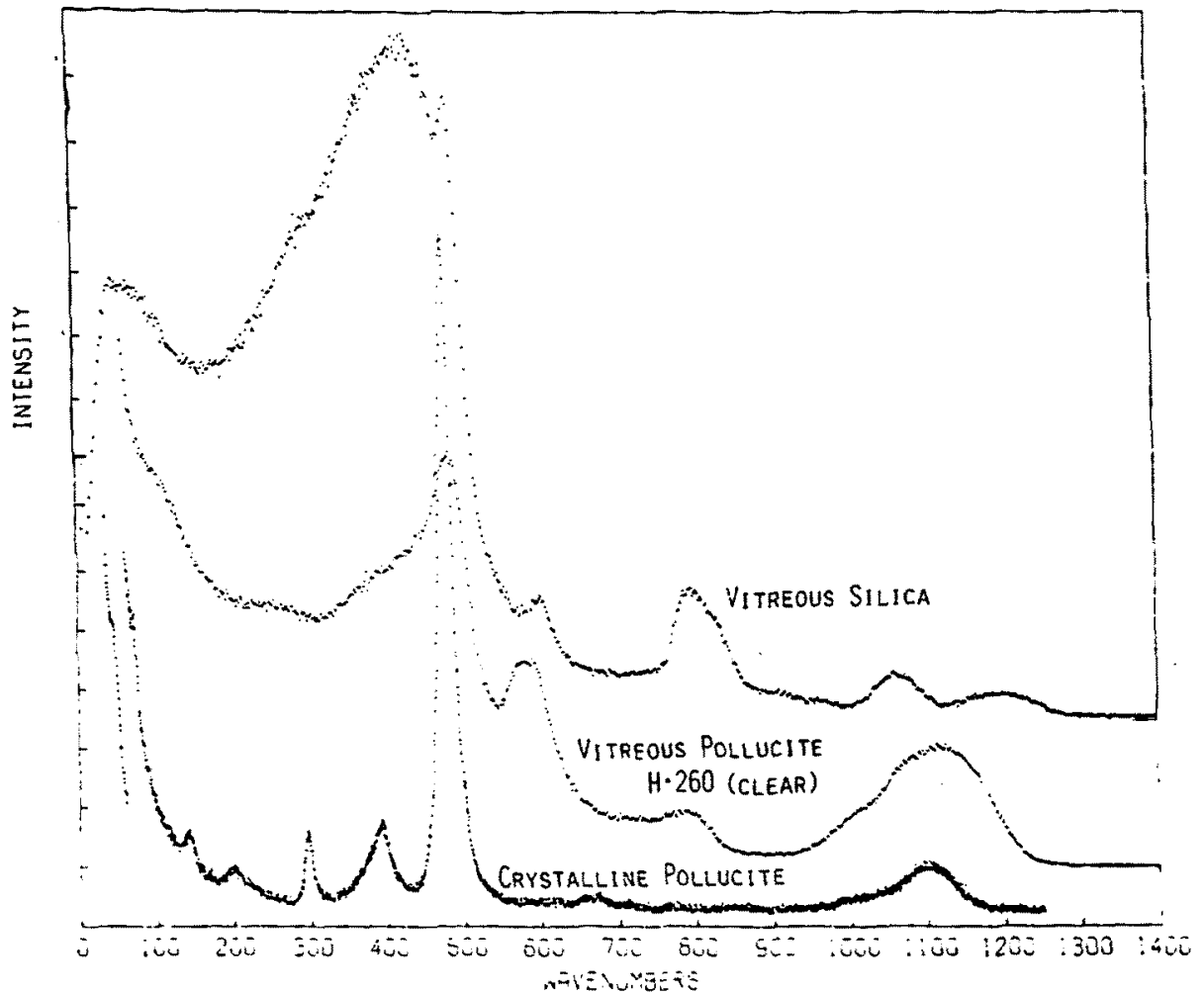

Figure 7 . A Comparison of Sam Snectra of Pure-Phase Cristallive Pollucite, ititreous pollucite an itreous Silica. 


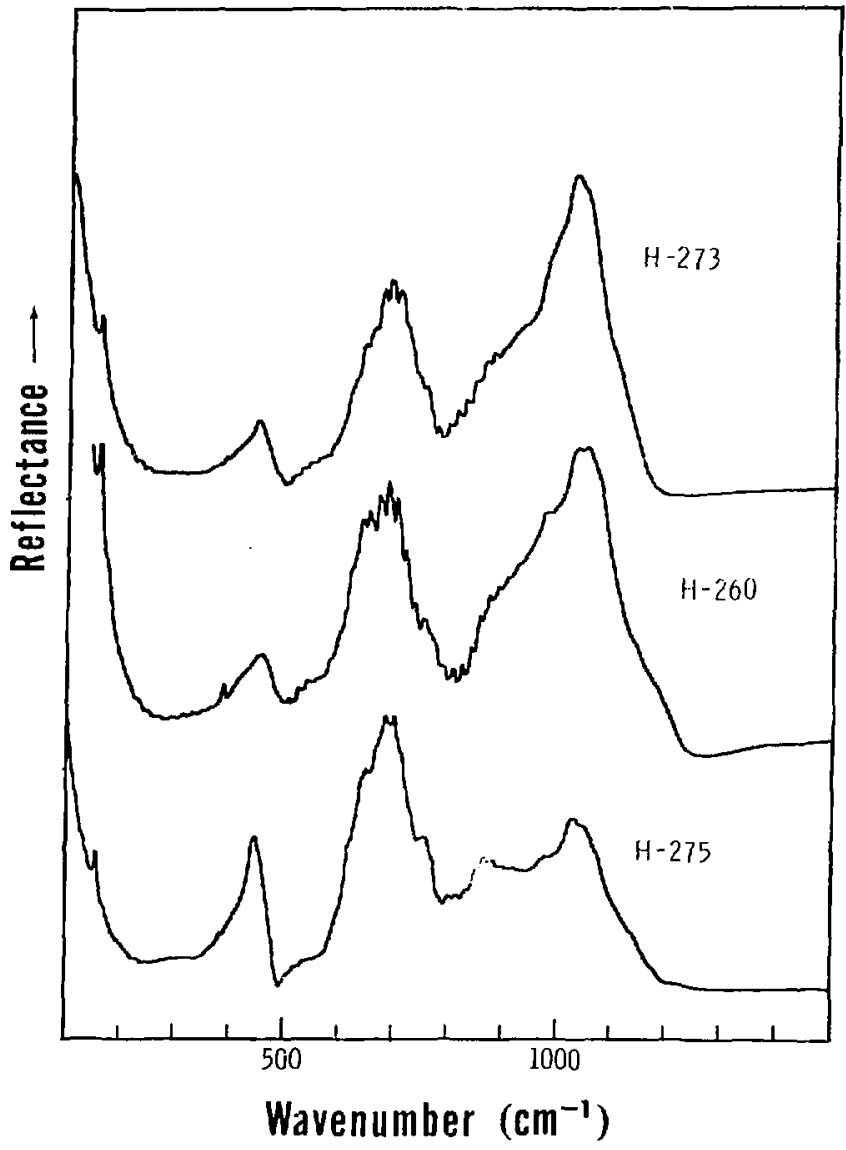

Figure 10. Infrared Reflection Spectra of Cesium Aluninosilicate Materials. 


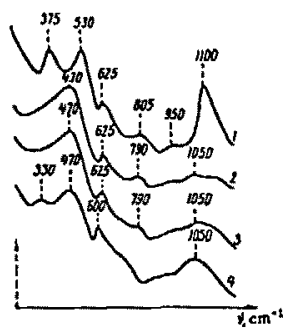

Figure 8. Raman Spectra of Sodiun Borosilicate Gusses. ${ }^{12}$ 


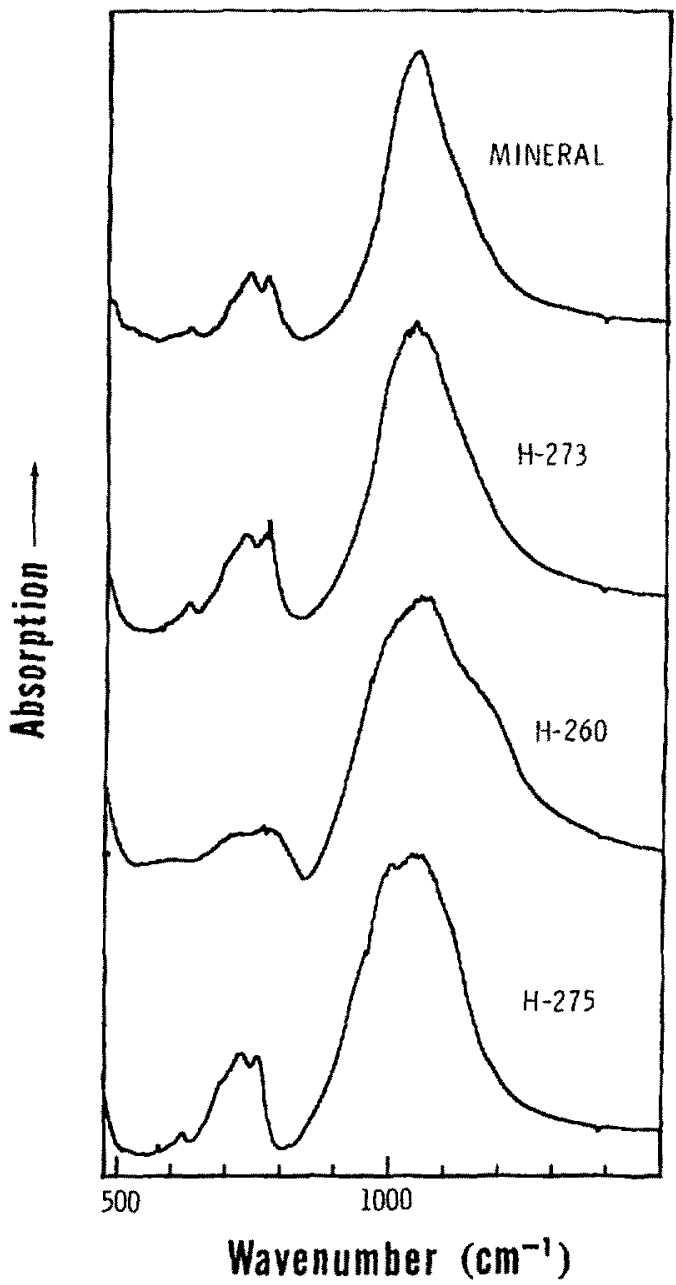

Figure 9. Infrared Absorption Spectra of Cesium Aluminosilicats Materials. 


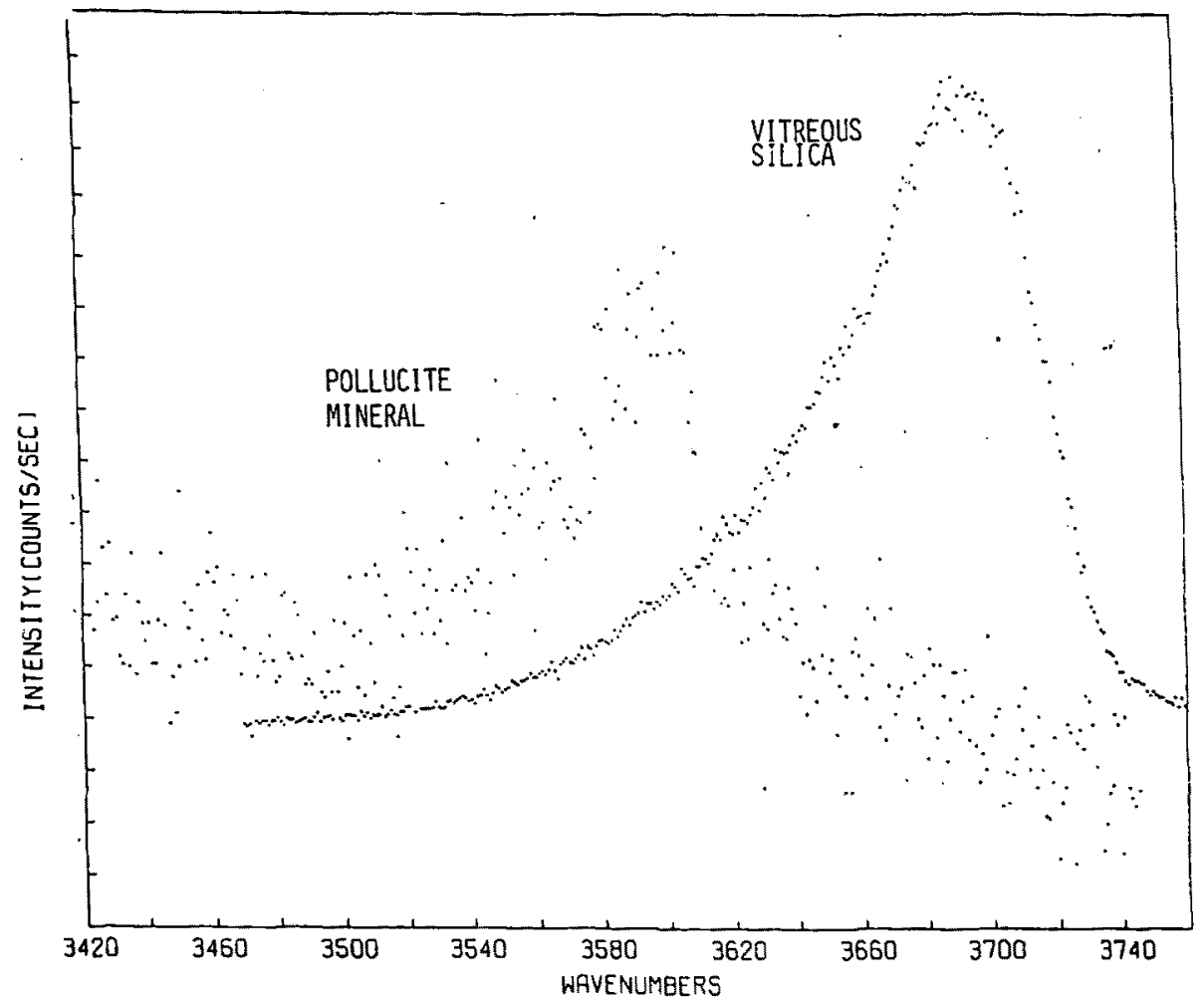

Figure 11. Ranan Spectrum of Wate: in the Nineral Pollucite. The Raman spectrum of hydroxyl in vitreous silica is included for reference. The band observed is due to the symetric stretch of the triatomic moleculc. 


$$
4 c
$$

